\title{
Herbicide Program Approaches for Managing Glyphosate-Resistant Palmer Amaranth (Amaranthus palmeri) and Waterhemp (Amaranthus tuberculatus and Amaranthus rudis) in Future Soybean-Trait Technologies
}

\author{
Christopher J. Meyer, Jason K. Norsworthy, Bryan G. Young, Lawrence E. Steckel, Kevin W. Bradley, \\ William G. Johnson, Mark M. Loux, Vince M. Davis, Greg R. Kruger, Mohammad T. Bararpour, \\ Joseph T. Ikley, Douglas J. Spaunhorst, and Thomas R. Butts*
}

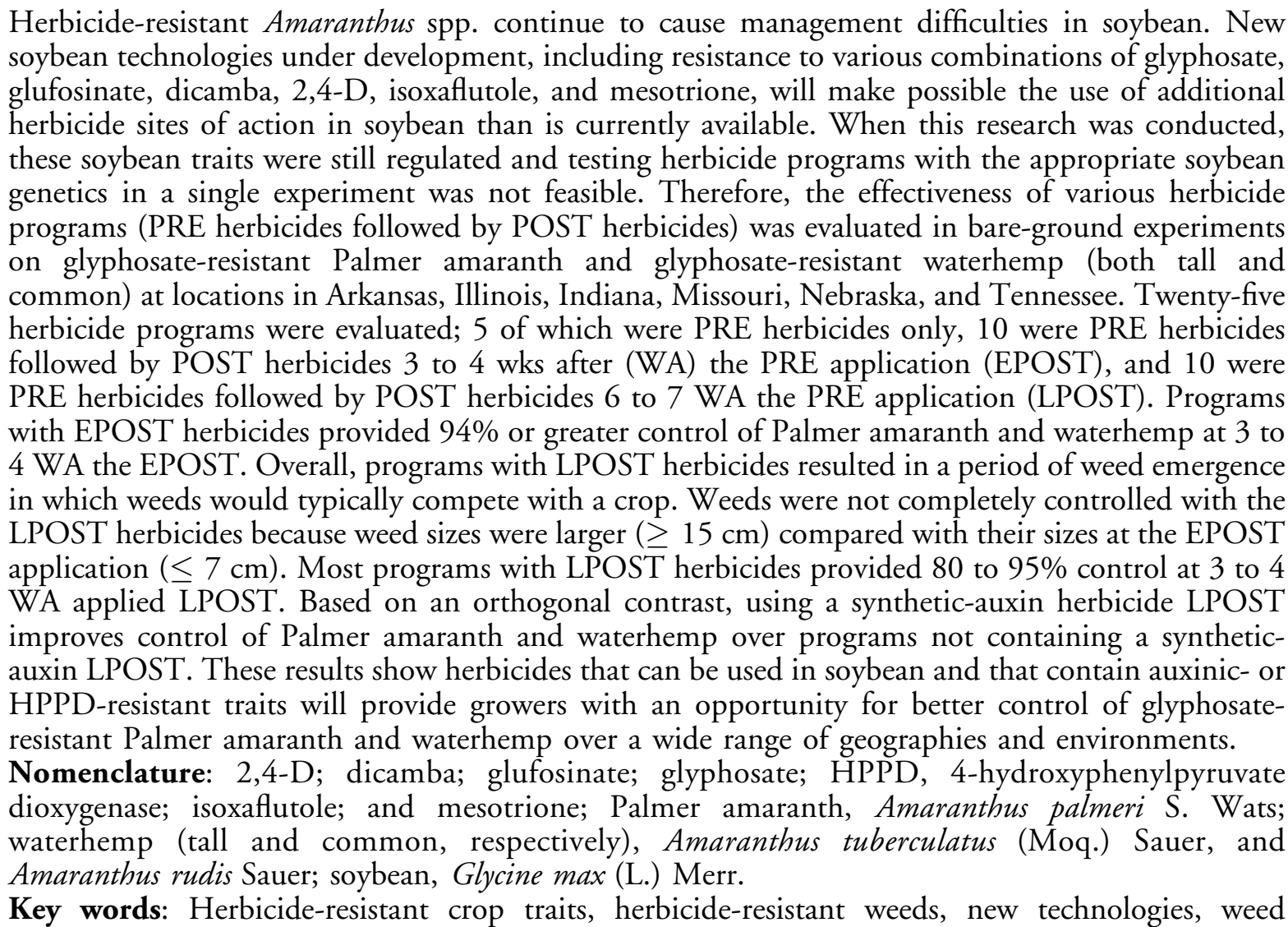
control.

\begin{abstract}
Amaranthus spp. resistentes a herbicidas continúan causando problemas de manejo en soja. Nuevas tecnologías para soja que están actualmente en desarrollo y que incluyen resistencia a varias combinaciones de glyphosate, glufosinate, dicamba, 2,4-D, isoxaflutole, y mesotrione, harán posible el uso de sitios de acción que no están actualmente disponibles para uso en soja. Cuando se realizó esta investigación, estas tecnologías estaban todavía bajo regulación y la evaluación de programas de
\end{abstract}

\footnotetext{
DOI: $10.1614 /$ WT-D-15-00045.1

* First, second, and tenth authors: Graduate Research Assistant, Professor, and Research Associate, Department of Crop Soil and Environmental Sciences, University of Arkansas, Fayetteville, AR 72704; third, sixth, eleventh, and twelfth authors: Associate Professor, Professor, Research Associate, and Graduate Research Assistant, Department of Botany and Plant Pathology, Purdue University, West Lafayette, IN 47907; fourth author: Associate Professor, Department of Plant Sciences, University of Tennessee, Knoxville, TN 37996; fifth author: Associate Professor, Division of Plant Sciences, University of Missouri, Columbia, MO 65211; seventh author: Professor, Ohio State University, Columbus, OH 43210; eighth and thirteenth authors: Former Assistant Professor and Graduate Research Assistant, Department of Agronomy, University of Wisconsin-Madison, Madison WI 53706; ninth author: Assistant Professor, University of Nebraska-Lincoln, North Platte, NE 69101. Corresponding author's E-mail: cjmeyer@uark.edu
} 


\begin{abstract}
herbicidas con la genética apropiada de soja en un solo experimento no era factible. Por esto, se evaluó la efectividad de varios programas de herbicidas (herbicidas PRE seguidos de herbicidas POST) en experimentos con suelo desnudo en localidades en Arkansas, Illinois, Indiana, Missouri, Nebraska, y Tennessee que tenían Amaranthus palmeri resistente a glyphosate y Amaranthus rudis y Amaranthus tuberculatus resistentes a glyphosate. Se evaluaron 25 programas de herbicidas; 5 de los cuales fueron solamente herbicidas PRE, 10 fueron herbicidas PRE seguidos por herbicidas POST 3 a 4 semanas después (WA) de la aplicación PRE (EPOST), y 10 fueron herbicidas PRE seguidos por herbicidas POST 6 a 7 WA de la aplicación PRE (LPOST). Los programas con herbicidas EPOST brindaron $94 \%$ de control o más de $A$. palmeri, $A$. tuberculatus, y $A$. rudis a 3 a 4 WA de la aplicación EPOST. En general, los programas con herbicidas LPOST resultaron en un período de emergencia de malezas en el cual las malezas típicamente competirían con el cultivo. Las malezas no fueron controladas completamente con los herbicidas LPOST porque el tamaño de las malezas fue mayor $(\geq 15 \mathrm{~cm})$ al compararse con su tamaño en la aplicación EPOST $(\geq 7 \mathrm{~cm})$. La mayoría de los programas con herbicidas LPOST brindaron 80 a $95 \%$ de control a 3 a 4 WA de la aplicación LPOST. Con base en un contraste ortogonal, el usar un herbicida de tipo auxina sintética LPOST mejoró el control de A. palmeri, A. rudis, y A. tuberculatus al compararse con programas que no contenían un herbicida de tipo auxina sintética LPOST. Estos resultados muestran que los herbicidas que pueden ser usados en soja resistente a herbicidas de tipo auxina o HPPD brindarán a los productores una oportunidad para controlar mejor $A$. palmeri, $A$. rudis, y $A$. tuberculatus resistentes a glyphosate, en un amplio rango de ambientes y geografías.
\end{abstract}

Twenty-five states in the United States have confirmed glyphosate-resistant (GR) Palmer amaranth populations, and 16 states have confirmed GR tall waterhemp populations (Heap 2015). Because the distinction between common waterhemp and tall waterhemp is increasingly difficult to make (Steckel 2007) and because no distinction is made on the International Survey of Herbicide Resistant Weeds (Heap 2015), these two species will be referred to collectively as waterhemp.

Palmer amaranth populations with multiple resistance to acetolactate synthase (ALS)-inhibiting herbicides and glyphosate are widespread in the midsouth (Bagavathiannan and Norsworthy 2013). Documentation of multiple resistance in waterhemp to herbicides from at least two sites of action is increasingly common. Of the fields sampled in Illinois and Missouri by Tranel et al. (2011), 5\% of them had plants resistant to ALS-, protoporphyrinogen oxidase (PPO)-inhibiting herbicides, and glyphosate. In 2012, more than one-half of the sampled populations in Missouri had confirmed resistance to at least two sites of action (Schultz et al. 2015). Waterhemp populations in Iowa have confirmed resistance to photosystem II (PSII)-, 5'-enolpyruvalshikimate-3-phosphate synthase (EPSPS)-, ALS-, and HPPD-inhibiting herbicides (Heap 2015). Plants from a waterhemp population in Illinois tested positive for resistance to EPSPS-, ALS-, PPO-, and PSII-inhibitors (Bell et al. 2013). Despite successful management strategies that have emerged and were implemented to manage GR Amaranthus spp. in the Midwest and midsouth, evolution of herbicide resistance across the United States shows no sign of slowing because growers continue to adopt reactive strategies once the resistance becomes a problem rather than a moreproactive approach (Heap 2015).

Palmer amaranth has been documented as the most competitive of the Amaranthus spp. for plant volume, dry weight, and leaf area produced per plant (Horak and Loughin 2000; Sellers et al. 2003). It is also considered one of the mosttroublesome weeds across the midsouth (Webster 2012, 2013), and GR Palmer amaranth has spread to most states in the Midwest. A recent survey estimates GR Palmer amaranth has cost soybean producers millions of dollars in financial losses in the midsouth (Riar et al. 2013). Within 4 wk of emergence with the crop, Palmer amaranth can outgrow soybean by $20 \mathrm{~cm}$ and, at densities of 10 plants $\mathrm{m}^{-2}$, cause yield losses exceeding 60\% (Bensch et al. 2003; Klingaman and Oliver 1994). Palmer amaranth annual emergence can exceed 1,000 plants $\mathrm{m}^{-2}$ from a natural seedbank, demonstrating the importance of effective control to prevent rapid population growth (Jha and Norsworthy 2009).

Amaranthus spp. possess numerous characteristics favoring their survival in current cropping systems, including high seed production, rapid growth rate, erect growth habit, extended emergence pattern, rapid seed production (able to reproduce a few weeks after emergence), acclimation to shading, and drought tolerance mechanisms (Bagavathiannan 2015; Horak and Loughin 2000; Jha and Norsworthy 2009; Jha et al. 2009; Keeley et al. 1987; Norsworthy et al. 2008; Sellers et al. 2003). The many reproductive advantages Amaranthus spp. use increase the likelihood of their persistence and 
evolution of resistance to herbicides in modern production systems.

The more individuals that are exposed to a single selection pressure, the greater the likelihood of evolving herbicide resistance. If the mutation rate for glyphosate-resistance alleles is set at $5 \times 10^{-9}$ (five per one billion individuals) (Neve et al. 2011), only 4,000 plants producing 250,000 seeds plant ${ }^{-1}$ are required to result in five of those seeds possessing resistance to glyphosate or a herbicide from another site of action with a similar mutation rate. Considering there were over 35 million ha planted in soybean in the United States in 2014 (USDA-NASS 2015), prolific seed producers, such as Amaranthus spp., are a serious threat for evolving resistance to any herbicide that is frequently used in production fields over a large geographical area. Therefore, rigorous weed-management programs, consisting of mechanical, cultural, and chemical control practices, are still needed to manage herbicide-resistant Amaranthus spp.

In 2016, the next-generation of herbicide-resistant soybean traits will begin to emerge on the commercial market. Eventually, varieties that are resistant to glyphosate, glufosinate, dicamba, 2,4-D, isoxaflutole, and mesotrione herbicides are expected to be commercialized for additional herbicide options. Various combinations of glyphosate, glufosinate, dicamba, and 2,4-D, applied POST, have proven to be effective for control of glyphosate-resistant weeds (Chahal and Johnson 2012; Craigmyle et al. 2013a,b). Furthermore, mesotrione and isoxaflutole (HPPD-inhibitors) are effective at controlling Amaranthus spp. (Johnson et al. 2012; Sutton et al. 2002). The objective of this research was to evaluate current and future herbicide programs that contain multiple, effective herbicide sites of action for the control of waterhemp and Palmer amaranth in six states located in soybeangrowing regions of the United States.

\section{Materials and Methods}

The effectiveness of herbicide programs were evaluated on glyphosate-resistant Palmer amaranth in 2013 and 2014 at locations in Arkansas, Indiana, Nebraska, Illinois, and Tennessee. The same programs were also evaluated on glyphosate-resistant waterhemp at locations in Illinois, Missouri, and Nebraska. Field experiments containing Palmer amaranth were conducted at the following locations: Northeast Research and Extension Center in Keiser, AR (clay); a grower field near Collinsville, IL (silt loam); a grower field near Twelve Mile, IN (fine-loamy sand); the University of Nebraska Lincoln Havelock Farm, Lincoln, NE (silty clay); and the West Tennessee Research and Education Center, Jackson, TN (silt loam). Locations that included waterhemp were as follows: a grower field near De Soto, IL (silt loam); a grower field near Moberly, MO (silt loam); and a grower field near Fremont, NE (silty clay). The fields at these locations were selected because they contained known glyphosate-resistant Amaranthus spp. populations. Thus, glyphosate was not considered as a herbicide with an effective site of action for controlling Amaranthus spp. at these locations. Rainfall and irrigation data can be found in Table 1 for the Palmer amaranth locations and in Table 2 for waterhemp locations.

In total, 25 herbicide programs were evaluated; 5 of which were PRE-only herbicides, 10 were PRE herbicides followed by POST herbicides at 3 to 4 wk after (WA) the PRE application (early POST [EPOST]), and the final 10 programs consisted of the same PRE herbicides followed by herbicides applied 6 to 7 WA the PRE application (late POST [LPOST]). Various combinations of flumioxazin $\left(70 \mathrm{~g}\right.$ ai ha $\left.{ }^{-1}\right)$, pyroxasulfone $\left(89 \mathrm{~g}\right.$ ai ha $\left.{ }^{-1}\right), S$ metolachlor (1,068 to $1,872 \mathrm{~g}$ ai ha $\left.^{-1}\right)$, metribuzin $\left(420\right.$ or $630 \mathrm{~g}$ ai ha $\left.{ }^{-1}\right)$, isoxaflutole $\left(105 \mathrm{~g} \mathrm{ai} \mathrm{ha}^{-1}\right)$, dicamba $\left(1,120 \mathrm{~g}^{-1} \mathrm{ha}^{-1}\right)$, acetochlor $(2,307 \mathrm{~g}$ ai $\mathrm{ha}^{-1}$ ), mesotrione (185 $\mathrm{g}$ ai ha ${ }^{-1}$ ), and fomesafen $\left(266 \mathrm{~g}\right.$ ai ha $\left.{ }^{-1}\right)$ were applied at trial initiation (PRE) and were followed by applications of various combinations of glyphosate (867 or $1,054 \mathrm{~g}$ ae $\left.\mathrm{ha}^{-1}\right), S$-metolachlor $\left(1,054\right.$ or $\left.1,068 \mathrm{~g}^{-1} \mathrm{ha}^{-1}\right)$, dicamba $\left(560 \mathrm{~g}^{-1}\right.$ ae ha $\left.{ }^{-1}\right)$, glufosinate $(594 \mathrm{~g}$ ai $\left.\mathrm{ha}^{-1}\right), 2,4-\mathrm{D}\left(1,065 \mathrm{~g}\right.$ ae ha $\left.{ }^{-1}\right)$, fomesafen (263 $\mathrm{g}$ ai $\mathrm{ha}^{-1}$ ), and mesotrione (105 $\mathrm{g}$ ai ha ${ }^{-1}$ ), either at 3 to 4 WA PRE or at 6 to 7 WA PRE (see Table 3 for a list of all the herbicides used in the experiment and Table 4 for complete list of the herbicide programs). When applied PRE, the rate of $S$-metolachlor was $1,068 \mathrm{~g} \mathrm{ai} \mathrm{ha}^{-1}$ unless it was part of a premix with fomesafen ( $S$-metolachlor at $1,216 \mathrm{~g}^{\text {ai h ha }}{ }^{-1}$ ) or mesotrione ( $S$-metolachlor at $1,872 \mathrm{~g}^{\text {ai ha }}{ }^{-1}$ ). When applied POST, the rate of $S$-metolachlor was $1,068 \mathrm{~g}$ ai ha ${ }^{-1}$ unless it was part of a premix with glyphosate + mesotrione $(S$-metolachlor at $1,054 \mathrm{~g}$ 
Table 1. Application information for Palmer amaranth site-years and rainfall data for each week after the PRE application. ${ }^{a}$

\begin{tabular}{|c|c|c|c|c|c|c|c|c|c|c|c|c|c|c|c|c|c|}
\hline \multirow[b]{3}{*}{ Location } & \multirow[b]{3}{*}{ Year } & \multirow[b]{3}{*}{ PRE } & \multirow[b]{3}{*}{ EPOST } & \multirow[b]{3}{*}{ LPOST } & \multicolumn{13}{|c|}{ Rainfall } \\
\hline & & & & & \multicolumn{13}{|c|}{ Weeks after PRE treatment } \\
\hline & & & & & 1 & 2 & 3 & $4^{\mathrm{b}}$ & 5 & 6 & $7^{\mathrm{c}, \mathrm{d}}$ & 8 & 9 & $10^{\mathrm{e}, \mathrm{f}}$ & 11 & 12 & 13 \\
\hline \multirow{2}{*}{ Keiser, AR } & 2013 & May 16 & June 6 & June 27 & 0.9 & 5.6 & 4.9 & 3.7 & 2.1 & 4.1 & 2.3 & 0.2 & 0.2 & 0.4 & 7.0 & 4.2 & \\
\hline & 2014 & May 23 & June 26 & July 10 & 0.0 & 4.7 & 6.1 & 6.1 & 0.5 & 7.6 & 3.9 & 1.9 & 2.3 & 0.3 & 0.2 & 2.6 & 0.0 \\
\hline Collinsville, IL & 2014 & June 3 & June 25 & July 16 & 4.4 & 4.1 & 2.0 & 1.2 & 0.1 & 1.6 & 0.7 & 0.0 & 0.1 & 11.2 & 1.6 & 3.4 & 0.1 \\
\hline \multirow[t]{2}{*}{ Twelve Mile, IN } & 2013 & May 23 & June 4 & June 25 & 1.1 & 0.3 & 7.3 & 0.1 & 5.2 & 0.2 & 0.7 & 3.5 & 3.0 & 0.2 & 2.7 & 0.0 & 1.2 \\
\hline & 2014 & May 1 & May 22 & June 12 & 0.3 & 1.0 & 5.2 & 0.0 & 0.0 & 2.1 & 3.3 & 1.1 & 2.0 & 1.1 & 0.6 & 1.5 & 0.9 \\
\hline \multirow[t]{2}{*}{ Lincoln, NE } & 2013 & May 23 & June 8 & June 31 & 2.3 & 13.9 & 2.5 & 0.6 & 0.1 & 3.1 & 0.0 & 0.0 & 0.0 & 0.7 & 3.7 & 0.0 & 0.9 \\
\hline & 2014 & May 8 & May 27 & June 19 & 0.8 & 7.6 & 1.8 & 3.1 & 6.8 & 0.0 & 5.8 & 2.4 & 0.0 & 0.8 & 0.3 & 0.2 & 0.2 \\
\hline \multirow[t]{2}{*}{ Jackson, TN } & 2013 & May 13 & June 3 & June 24 & 2.1 & 8.4 & 3.8 & 1.8 & 1.9 & 2.0 & 0.6 & 3.0 & 0.2 & 1.8 & 7.4 & 2.3 & 1.2 \\
\hline & 2014 & May 7 & May 27 & June 16 & 1.0 & 7.0 & 0.0 & 1.7 & 15.8 & 9.0 & 0.0 & 2.9 & 5.0 & 2.3 & 5.2 & 1.4 & 0.0 \\
\hline Mean & & & & & 1.4 & 5.8 & 3.7 & 2.0 & 3.6 & 3.3 & 1.9 & 1.7 & 1.4 & 2.1 & 3.2 & 1.7 & 1.0 \\
\hline
\end{tabular}

${ }^{a}$ Abbreviations: EPOST, early POST; LPOST, late POST.

${ }^{\mathrm{b}}$ EPOST application occurred during or near the fourth week (21 to $28 \mathrm{~d}$ ) after the PRE treatment.

${ }^{\mathrm{c}}$ LPOST application occurred during or near the seventh week ( 42 to $49 \mathrm{~d}$ ) after the PRE treatment.

${ }^{d}$ The 3 to 4 wk after EPOST rating was collected during or near the seventh week after the PRE treatment, before the LPOST application.

${ }^{\mathrm{e}}$ The 3 to $4 \mathrm{wk}$ after LPOST rating was collected during or near the tenth week (63 to $70 \mathrm{~d}$ ) after the PRE treatment.

${ }^{\mathrm{f}}$ At the Arkansas location, in 2014 only, plots were furrow-irrigated to field capacity.

ai ha ${ }^{-1}+$ glyphosate $1,054 \mathrm{~g}$ ae $\mathrm{ha}^{-1}+$ mesotrione at $105 \mathrm{~g}_{\text {ai }} \mathrm{ha}^{-1}$ ). Similarly, the rate of glyphosate was $867 \mathrm{~g}$ ae ha ${ }^{-1}$, unless it was a part of the same premix of $S$-metolachlor + glyphosate + mesotrione. The rate of metribuzin was adjusted for the soil texture and soil organic matter $(\mathrm{OM})$ present at a given location according to labeled recommendations. Metribuzin was applied at $420 \mathrm{~g}_{\text {ai ha }}{ }^{-1}$ on coarser-textured or lower soil OM sites, including Havelock, NE; Fremont, NE; and Twelve Mile, IN, and at $630 \mathrm{~g}^{2} \mathrm{ha}^{-1}$ on fine- or medium-textured or greater soil $\mathrm{OM}$ sites, including Keiser, AR;

Table 2. Application information for waterhemp site-years and rainfall data for each week after the PRE application. ${ }^{a}$

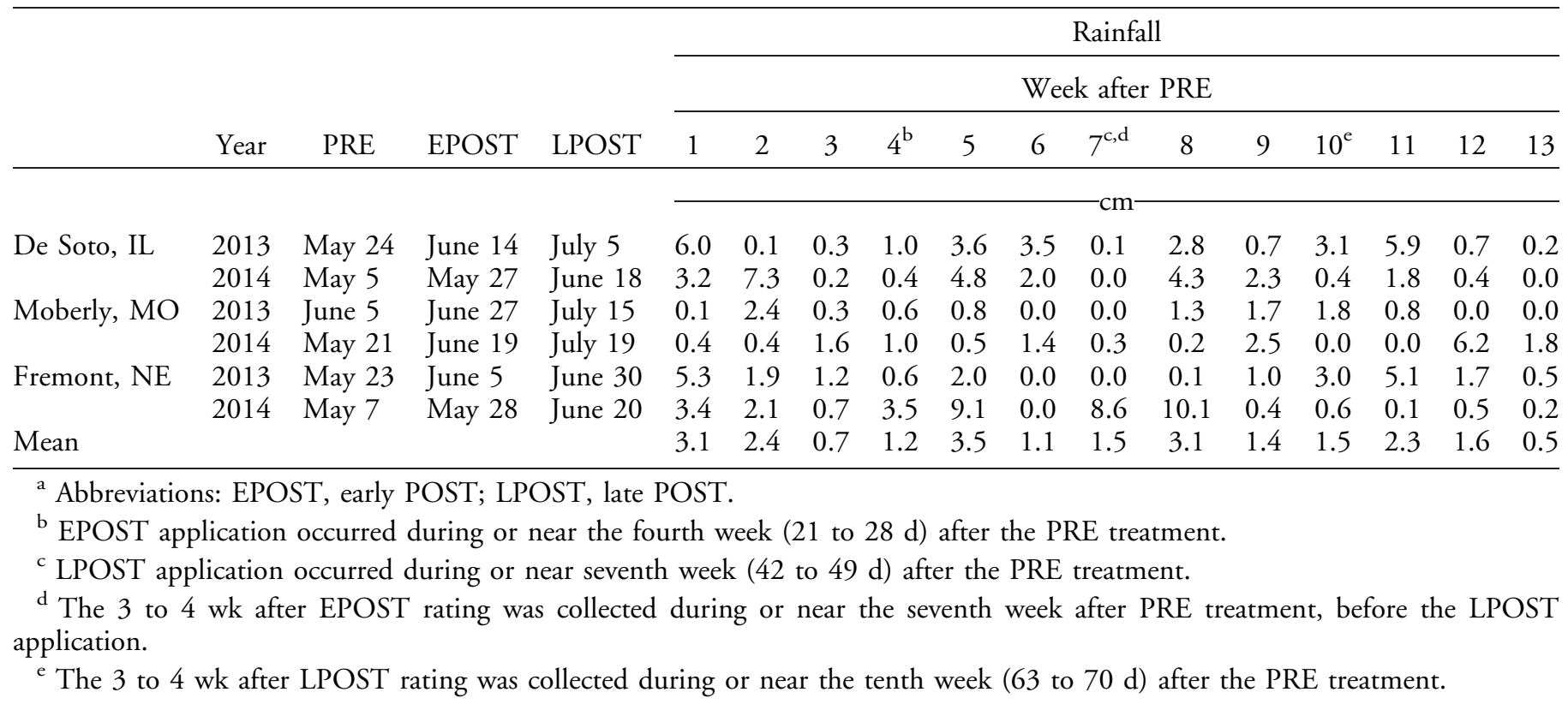


Table 3. Herbicide information for all products used in the experiments. ${ }^{a}$

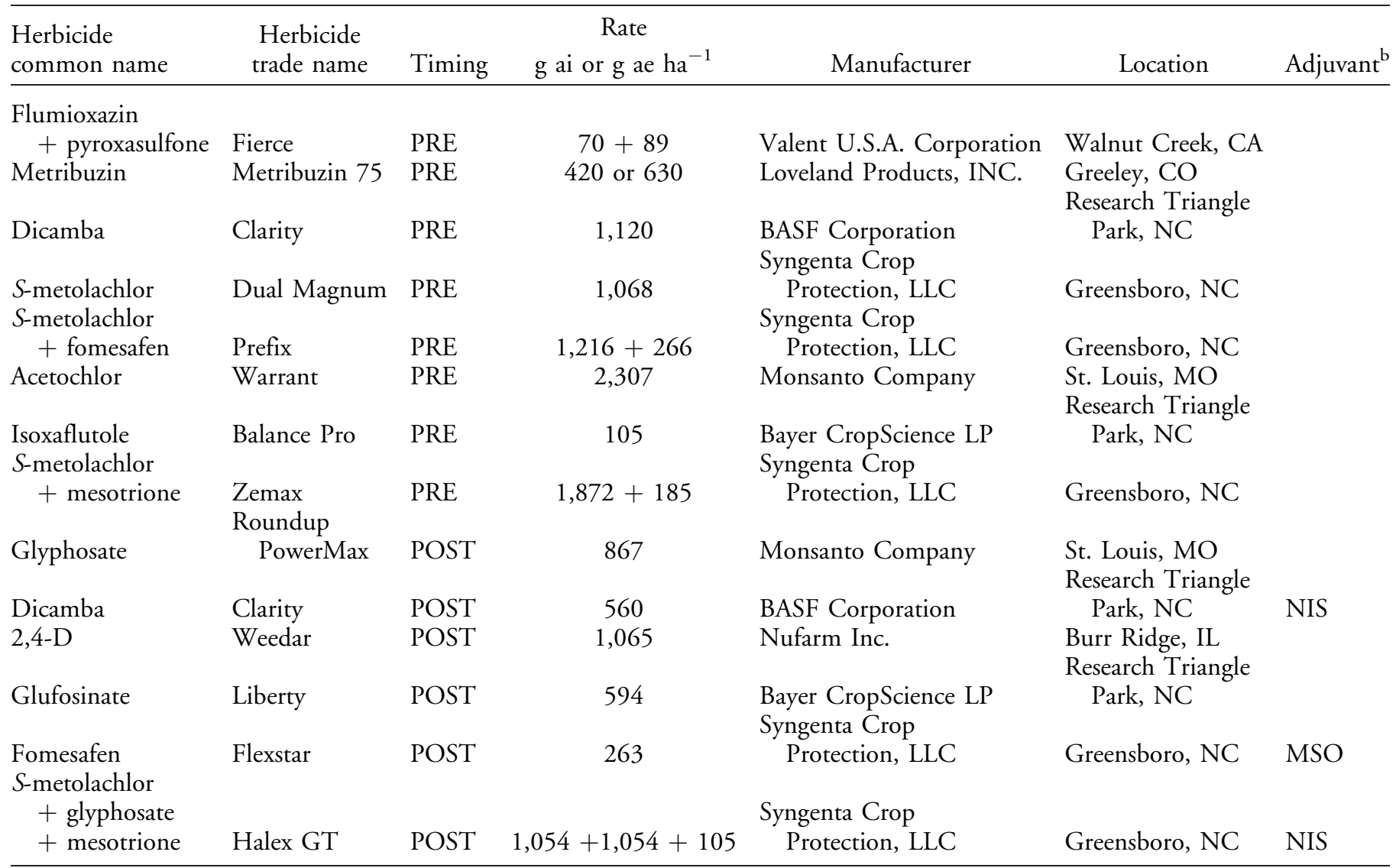

a Abbreviations: NIS, nonionic surfactant (Helena Chemical Company, Collierville, TN); MSO, methylated seed oil (Helena Chemical Company, Collierville, TN).

b Adjuvant rates: NIS, $0.25 \% \mathrm{v} / \mathrm{v} ; \mathrm{MSO}, 1 \% \mathrm{v} / \mathrm{v}$.

Collinsville, IL; De Soto, IL; Moberly, MO, and Jackson, TN. Herbicides included in these experiments are either currently available or are herbicides that were program concepts for use in the developmental herbicide-resistant soybean technologies.

Plot sizes were approximately $3.9 \mathrm{~m}$ by $7.6 \mathrm{~m}$ at each location. Plots size differed slightly among locations, primarily as a function of the row-spacing common to individual locations (e.g., in Arkansas, the trial area was bedded to facilitate furrow irrigation, with beds spaced $97 \mathrm{~cm}$ apart). No soybean variety was available that was resistant to all of the herbicides included in this experiment. The goals were to compare current and future herbicide programs in the same experiment and to identify those that provide the greatest control of Amaranthus spp. Therefore, no crop was planted at the trial locations. Typical preplanting procedures (tillage, applying nonresidual burndown herbicides, etc.) common to each individual state were used to prepare a weed-free area at the time of trial establishment. Application of POST herbicides were targeted for 3 and 6 WA PRE (EPOST and LPOST, respectively) and ratings were targeted for 3 WA each application timing. Because of variables that exist among sites and between years, such as weather, EPOST applications were made within the range of 3 to 4 WA PRE, whereas LPOST herbicides were applied within the range of 6 to 7 WA PRE, and data were collected within 3 to 4 WA each application. Weed-control ratings were visually assessed and based on a scale of 0 to $100 \%$ control relative to the nontreated check, with $0 \%$ being no control and $100 \%$ being death of all weeds of that species. Weed counts (plants $\mathrm{m}^{-2}$ ) were collected by counting the number of individuals in two $0.5-\mathrm{m}^{-2}$ quadrats in each plot. Counts were taken at the 
same time as the weed-control ratings, both at 3 to $4 \mathrm{WA}$ EPOST and at 3 to $4 \mathrm{WA} \mathrm{LPOST}$.

Data Analysis. All data were analyzed in JMP Pro 11 (SAS Institute., 100 SAS Campus Drive, Cary, NC 27513-2414) using the MIXED procedure. Data were pooled across location, and siteyear and replication were included in the model as random variables. Means were separated using Fisher's protected LSD test $(\alpha=0.05)$, and orthogonal contrasts were conducted for unique groups of herbicide programs $(\alpha=0.05)$. In 2013, the Collinsville, IL, site (Palmer amaranth) experienced excessive rainfall that resulted in surface movement of all PRE herbicides across the field site; thus, the experiment was abandoned. Weed counts were not collected for either location in Nebraska in 2014, so pooled data for weed counts do not contain information from those sites in 2014. For the 3 to 4 WA LPOST rating, ratings for the programs with only PRE herbicides were excluded from analysis because of high variability and many herbicides declining to near $0 \%$ control (data not shown). Thus, inclusion of the programs with only PRE herbicides at the 3 to 4 WA LPOST rating resulted in data that did not meet the equal variance assumptions for ANOVA. Weed densities were normalized for each location by converting them to a percentage relative to the average count in the nontreated check plots. Thus, locations with high densities $\left(>100\right.$ plants $\mathrm{m}^{-2}$ ) and locations with low densities $\left(10 \mathrm{~m}^{-2}\right)$ could be compared. Where appropriate, densities were also subjected to a natural $\log$ transformation to improve normality, and results were back-transformed for discussion.

\section{Results and Discussion}

Palmer Amaranth Control. All PRE-only programs provided $\geq 95 \%$ Palmer amaranth control at 3 to 4 WA PRE (data not shown). Six to seven WA PRE, Palmer amaranth control was $>85 \%$ for flumioxazin + pyroxasulfone, $S$-metolachlor + metribuzin + isoxaflutole, $S$-metolachlor + mesotrione + metribuzin, and $S$-metolachlor + fomesafen + metribuzin (Figure 1). However, Palmer amaranth control with dicamba + acetochlor declined to only $80 \%$ at 6 to 7 WA PRE. Similarly, Palmer amaranth density for flumioxazin + pyroxasulfone was $8 \%$ relative to the nontreated control and was significantly less than dicamba + acetochlor (24\%) at 3 to 4 WA EPOST (Table 4). At the 3 to 4 WA EPOST rating, the LPOST herbicides had not yet been applied. As would be expected, all programs with a LPOST herbicides were not significantly different from their respective PRE-only program for both weed control and plant counts.

All programs that consisted for PRE followed by (fb) EPOST timings provided $\geq 95 \%$ control of Palmer amaranth at 3 to 4 WA the EPOST application (Figure 1). Weed densities were also reduced for all programs with an EPOST herbicides to $\leq 5 \%$, relative to the densities in the nontreated controls (Table 4). More differences between programs were observed at the 3 to 4 WA LPOST rating than at the 3 to $4 \mathrm{WA}$ EPOST rating. All programs that used dicamba or 2,4-D LPOST had $>90 \%$ control of Palmer amaranth at 3 to 4 WA LPOST and were numerically greater that all programs that did not contain auxinic herbicides LPOST (Figure 2). However, just because a program included an auxinic-herbicide LPOST application did not mean it was significantly different than those programs that did not. For example, flumioxazin + pyroxasulfone PRE $\mathrm{fb} S$ metolachlor + glyphosate + 2,4-D LPOST (91\% control) was not different than $S$-metolachlor + mesotrione + metribuzin PRE fb fomesafen LPOST $(85 \%$ control). The programs that provided the greatest control at both rating timings consisted of PRE $\mathrm{fb}$ POST applications using three or more sites of action (Figures 1 and 2).

Overall, control was greater for programs with LPOST herbicides than it was for programs with EPOST herbicides at 3 to 4 WA LPOST application, and an orthogonal contrast shows a significant difference between programs with EPOST herbicides and programs with LPOST herbicides (Table 5). This indicates that by the 3 to 4 WA LPOST rating, herbicide programs with a residual herbicide included in the EPOST application were no longer providing residual control, leading to new emergence. However, a different situation occurred with programs with LPOST herbicide applications. Data collected immediately before the LPOST application (weed control at 3 to 4 WA EPOST) show Palmer amaranth plants were present in the plots at the time of application (15 to $25 \mathrm{~cm}$ tall, depending on location) and were not 


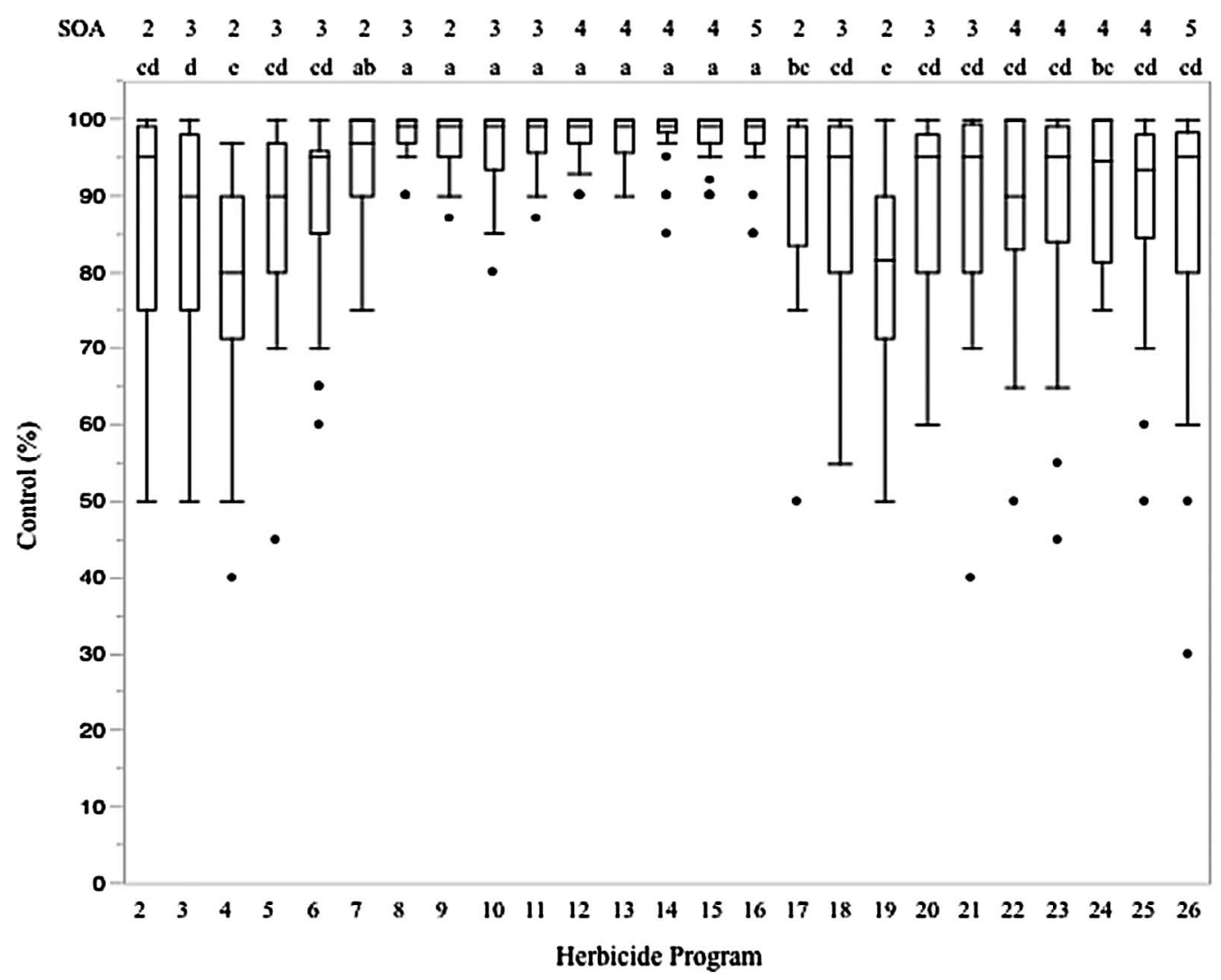

Figure 1. Box and whisker plots depicting the Palmer amaranth percentage of control 3 to 4 wk after early POST for each herbicide program and the number of effective sites of action (SOAs). Means of herbicide programs sharing the same letter are not significantly different according to Fisher's protected LSD $(\alpha=0.05)$. Herbicide program corresponds to the appropriate number listed in Table 4 .

fully controlled at 3 to 4 WA LPOST application. Relating this to a situation with an actual crop, having plants not fully controlled by LPOST herbicides is less desirable than applying EPOST herbicides and risking emergence 3 to 4 wk later. Weeds present at the time of a POST application have already competed with the crop for light, water, nutrients and other necessities and may have already caused yield reductions (Bensch et al. 2003; Klingaman and Oliver 1994). Conversely, weed emergence is reduced under a crop canopy (Jha and Norsworthy 2009) compared with an area without a crop canopy. Also, later-emerging weeds may be controlled with a second POST herbicide application.

Comparing only technologies that contained either HPPD- or synthetic auxin-resistance traits at the 3 to 4 WA LPOST rating, the two technologies were significantly different when applied EPOST (0.0011) and LPOST (0.0002) (Table 5). When fomesafen or mesotrione was applied EPOST, ratings at 3 to 4 WA LPOST were higher than programs containing an auxinic herbicide EPOST. Conversely, including an auxinic herbicide LPOST provided greater control of Palmer amaranth than did programs with fomesafen or mesotrione LPOST. Programs containing either a dicamba- or 2,4-D-resistance trait were not significantly different. Overall, new technologies performed better for controlling Palmer amaranth than did glyphosate- or glufosinate-resistant systems $(\mathrm{P}<0.0001)$. Orthogonal contrasts were also conducted on the plant-density data collected at 3 to 4 WA LPOST application. Results from contrasts on the density data were similar to the results for the weed-control data, except for the contrasts between HPPD and auxin technologies EPOST and LPOST (not significant). This discrepancy may be explained by densities not taking into account the size of the plants, which would be a factor in the weed-control rating.

Waterhemp Control. All programs with only PRE herbicides provided at $\geq 95 \%$ control of water- 
hemp at 3 to 4 WA application (data not shown). Waterhemp control at 6 to 7 WA PRE treatment (same as the 3 to 4 WA EPOST rating) was $>90 \%$ for dicamba + acetochlor only. $S$-metolachlor + mesotrione + metribuzin and $S$-metolachlor + fomesafen + metribuzin had $<90 \%$ control but were not significantly different from dicamba + acetochlor (Figure 3). Flumioxazin + pyroxasulfone had the least control (73\% control) of the PRE-only programs at 3 to $4 \mathrm{WA}$ EPOST treatment. Unlike the Palmer amaranth locations, dicamba + acetochlor provided the greatest control of waterhemp $(92 \%)$ and had the lowest weed density $(6 \%)$ at 3 to 4 WA EPOST application.

The differing performances of acetochlor and flumioxazin + pyroxasulfone between waterhemp and Palmer amaranth may be due to slight differences in sensitivity between the two species and differences in soil activity and persistence of the residual products across locations. Acetochlor requires $1.2 \mathrm{~cm}$ of rainfall to incorporate the product into the soil solution (Anonymous 2011). Among the Palmer amaranth locations, only Illinois in 2014, Nebraska in 2013, and Tennessee in 2013 had $>1.2 \mathrm{~cm}$ of rainfall in the first week after PRE treatment. Among the waterhemp locations, Missouri in both years had $<1.2 \mathrm{~cm}$ of rainfall; however, Illinois and Nebraska had $>3 \mathrm{~cm}$ the first week after PRE treatment. Unlike acetochlor, the flumioxazin + pyroxasulfone treatment does not have any requirement for rainfall incorporation on the product label (Anonymous 2013). Additionally, the flumioxazin + pyroxasulfone treatment is more likely to have a decrease in activity compared with acetochlor after $2.4 \mathrm{~cm}$ of rainfall has occurred (Anonymous 2013. The difference in amount of rainfall needed to incorporate acetochlor into the soil solution, compared with flumioxazin + pyroxasulfone, may have contributed to the differences in control between waterhemp and Palmer amaranth. Furthermore, other confounding factors, such as climate, soil organic matter, and soil texture differences, may be influencing efficacy between the waterhemp and Palmer amaranth sites.

All programs with EPOST herbicides provided $96 \%$ control of waterhemp at 3 to 4 WA EPOST application (Figure 3) and reduced waterhemp density to $\leq 1 \%$ of the density in the nontreated control (Table 4). The one exception was for the flumioxazin + pyroxasulfone applied PRE fb $S$ - metolachlor + glyphosate, a labeled application in glyphosate-resistant soybean, which controlled glyphosate-resistant waterhemp 94\% and reduced waterhemp density to $5 \%$. By 3 to 4 WA LPOST treatment, flumioxazin + pyroxasulfone applied PRE $\mathrm{fb}$ a $S$-metolachlor + glyphosate application, which contains no effective sites of action with POST activity, provided only 74\% control (Figure 4 ). The programs that provided the greatest control at both rating timings typically consisted of PRE $\mathrm{fb}$ POST applications using three or more sites of action (Figures 3 and 4), with the exception of dicamba + acetochlor applied PRE fb $S$-metolachlor + glyphosate + dicamba applied LPOST (two sites of action).

No difference existed between technologies that included an auxinic or HPPD-resistance trait when applied EPOST but were different when applied LPOST, with auxinic herbicides providing better control $(\mathrm{P}=0.0018$ ) (Table 5). An orthogonal contrast between programs containing either a dicamba or 2,4-D treatment showed no difference between those technologies, and future technologies performed better than current technologies $(\mathrm{P}<0.0001)$. Contrasts on weed densities were similar to the weed-control contrasts for the EPOST vs. $\operatorname{LPOST}(\mathrm{P}=0.0056)$, current vs. future technologies (0.0006), and 2,4-D vs. dicamba technologies (not significant [NS]) but not for auxin vs. HPPD technologies applied EPOST (0.0001) and auxin vs. HPPD technologies applied LPOST (NS). These discrepancies are likely due to the lower weed-control ratings of the two programs containing fomesafen applied EPOST and, at the same time, having lower weed densities. This would suggest the plants that survived glyphosate + fomesafen applied EPOST were large by the 3 to 4 WA LPOST rating.

Even though programs with EPOST herbicides provided less control than did programs with LPOST herbicides at 3 to 4 WA LPOST application, waiting until 6 to 7 WA PRE treatment to make a POST application gave weeds a longer opportunity to emerge and to compete with the crop. The critical weed-free period to prevent yield loss in soybean is emergence up to the V1 to V4 stage (Knezevic et al. 2003; Van Acker et al. 1993) and is dependent on the climate, row spacing, weed species, weed density, and potentially other 
Table 4. Glyphosate-resistant Palmer amaranth and waterhemp density adjusted as a percentage of the nontreated control for each herbicide program with data collected 3 to $4 \mathrm{wk}$ after EPOST and 3 to 4 wk after LPOST.,

\begin{tabular}{|c|c|c|c|c|c|c|c|c|}
\hline \multirow[b]{2}{*}{$\begin{array}{l}\text { Program } \\
\text { No. } \\
\end{array}$} & \multirow[b]{2}{*}{$\begin{array}{c}\text { PRE } \\
\text { herbicide }\end{array}$} & \multirow[b]{2}{*}{$\begin{array}{c}\text { POST } \\
\text { herbicide }\end{array}$} & \multirow[b]{2}{*}{ SOA } & \multirow[b]{2}{*}{$\begin{array}{l}\text { POST } \\
\text { timing }\end{array}$} & \multicolumn{2}{|c|}{ Palmer amaranth } & \multicolumn{2}{|c|}{ Waterhemp } \\
\hline & & & & & $\begin{array}{l}3-4 \text { WA } \\
\text { EPOST }\end{array}$ & $\begin{array}{l}\text { 3-4 WA } \\
\text { LPOST }\end{array}$ & $\begin{array}{l}3-4 \text { WA } \\
\text { EPOST }\end{array}$ & $\begin{array}{l}\text { 3-4 WA } \\
\text { LPOST }\end{array}$ \\
\hline 1 & Nontreated & & & - & 100 & 100 & 100 & 100 \\
\hline 2 & $\begin{array}{l}\text { Flumioxazin } \\
\quad+\text { pyroxasulfone }\end{array}$ & & 2 & - & 8 efghi & - & $13 \mathrm{abcd}$ & - \\
\hline 3 & $\begin{array}{l}\text { S-metolachlor } \\
\quad+\text { isoxaflutole } \\
\quad+\text { metribuzin }\end{array}$ & & 3 & - & $23 \mathrm{ab}$ & - & 10 bcdef & - \\
\hline 4 & Dicamba + acetochlor & & 2 & - & $24 \mathrm{a}$ & - & 6 efghi & - \\
\hline 5 & $\begin{array}{l}\text { S-metolachlor } \\
\quad+\text { mesotrione } \\
\quad+\text { metribuzin }\end{array}$ & & 3 & - & $17 \mathrm{abcd}$ & - & $13 \mathrm{abcd}$ & - \\
\hline 6 & $\begin{array}{l}S \text {-metolachlor } \\
\quad+\text { fomesafen } \\
\quad+\text { metribuzin }\end{array}$ & & 3 & - & 12 defg & - & 6 efg & - \\
\hline 7 & $\begin{array}{l}\text { Flumioxazin } \\
\quad+\text { pyroxasulfone }\end{array}$ & $\begin{array}{l}S \text {-metolachlor } \\
\quad+\text { glyphosate }\end{array}$ & 2 & EPOST & 5 ghi & $32 \mathrm{ab}$ & 5 fghi & $14 \mathrm{a}$ \\
\hline 8 & $\begin{array}{l}\text { Flumioxazin } \\
\quad+\text { pyroxasulfone }\end{array}$ & $\begin{array}{l}\text { S-metolachlor } \\
\quad+\text { glyphosate } \\
\quad \text { + dicamba }\end{array}$ & 3 & EPOST & $1 \mathrm{hi}$ & $32 \mathrm{abc}$ & 1 ghi & $14 \mathrm{a}$ \\
\hline 9 & $\begin{array}{l}\text { Dicamba } \\
\quad+\text { acetochlor }\end{array}$ & $\begin{array}{l}\text { S-metolachlor } \\
\quad+\text { glyphosate } \\
\quad+\text { dicamba }\end{array}$ & 2 & EPOST & $1 \mathrm{hi}$ & $22 \mathrm{abcd}$ & $0 \mathrm{i}$ & $15 \mathrm{a}$ \\
\hline 10 & $\begin{array}{l}\text { Flumioxazin } \\
\quad+\text { pyroxasulfone }\end{array}$ & $\begin{array}{l}S \text {-metolachlor } \\
\quad+\text { glufosinate }\end{array}$ & 3 & EPOST & $2 \mathrm{hi}$ & $29 \mathrm{abcd}$ & 0 hi & $12 \mathrm{abc}$ \\
\hline 11 & $\begin{array}{l}\text { Flumioxazin } \\
\quad+\text { pyroxasulfone }\end{array}$ & $\begin{array}{l}\text { S-metolachlor } \\
\quad+\text { glyphosate } \\
\quad+2,4-\mathrm{D}\end{array}$ & 3 & EPOST & $1 \mathrm{i}$ & $34 \mathrm{a}$ & $0 \mathrm{i}$ & $13 \mathrm{ab}$ \\
\hline 12 & $\begin{array}{l}\text { Flumioxazin } \\
\qquad+ \text { pyroxasulfone }\end{array}$ & $\begin{array}{l}\text { S-metolachlor } \\
\quad+\text { glyphosate } \\
\quad+2,4-\mathrm{D} \\
\quad+\text { glufosinate }\end{array}$ & 4 & EPOST & $1 \mathrm{i}$ & $34 \mathrm{a}$ & 1 ghi & $11 \mathrm{abcd}$ \\
\hline 13 & $\begin{array}{l}\text { S-metolachlor } \\
\quad+\text { isoxaflutole } \\
\quad+\text { metribuzin }\end{array}$ & $\begin{array}{l}\text { Glyphosate } \\
\quad+\text { fomesafen }\end{array}$ & 4 & EPOST & $0 \mathrm{i}$ & $18 \mathrm{abcd}$ & $0 \mathrm{i}$ & $2 g$ \\
\hline 14 & $\begin{array}{l}S \text {-metolachlor } \\
\quad+\text { mesotrione } \\
\quad+\text { metribuzin }\end{array}$ & fomesafen & 4 & EPOST & $1 \mathrm{i}$ & 16 abcd & $0 \mathrm{i}$ & $4 \mathrm{efg}$ \\
\hline 15 & $\begin{array}{l}S \text {-metolachlor } \\
\quad+\text { fomesafen } \\
\quad+\text { metribuzin }\end{array}$ & $\begin{array}{l}\text { S-metolachlor } \\
\quad+\text { glyphosate } \\
\quad+\text { mesotrione }\end{array}$ & 4 & EPOST & $1 \mathrm{i}$ & 35 a & $1 \mathrm{hi}$ & $11 \mathrm{abcd}$ \\
\hline 16 & $\begin{array}{l}\text { S-metolachlor } \\
\quad+\text { fomesafen } \\
\quad+\text { metribuzin }\end{array}$ & $\begin{array}{l}\text { S-metolachlor } \\
\quad+\text { glyphosate } \\
\quad+\text { mesotrione } \\
\quad+\text { dicamba }\end{array}$ & 5 & EPOST & $2 \mathrm{hi}$ & $30 \mathrm{abcd}$ & $0 \mathrm{i}$ & 9 abcdefg \\
\hline 17 & $\begin{array}{l}\text { Flumioxazin } \\
\quad+\text { pyroxasulfone }\end{array}$ & $\begin{array}{l}\text { S-metolachlor } \\
\quad+\text { glyphosate }\end{array}$ & 2 & LPOST & 7 fghi & $30 \mathrm{abcd}$ & $18 \mathrm{a}$ & $14 \mathrm{a}$ \\
\hline 18 & $\begin{array}{l}\text { Flumioxazin } \\
\qquad+ \text { pyroxasulfone }\end{array}$ & $\begin{array}{l}\text { S-metolachlor } \\
\quad+\text { glyphosate } \\
\quad+\text { dicamba }\end{array}$ & 3 & LPOST & 9 defgh & $9 \mathrm{~d}$ & $15 \mathrm{abc}$ & $5 \mathrm{defg}$ \\
\hline 19 & $\begin{array}{l}\text { Dicamba } \\
\quad+\text { acetochlor }\end{array}$ & $\begin{array}{l}\text { S-metolachlor } \\
\quad+\text { glyphosate } \\
\quad+\text { dicamba }\end{array}$ & 2 & LPOST & $22 \mathrm{abc}$ & $11 \mathrm{~cd}$ & 8 def & $3 \mathrm{~g}$ \\
\hline
\end{tabular}


Table 4. Continued.

\begin{tabular}{|c|c|c|c|c|c|c|c|c|}
\hline \multirow[b]{2}{*}{$\begin{array}{l}\text { Program } \\
\text { No. }\end{array}$} & \multirow[b]{2}{*}{$\begin{array}{c}\text { PRE } \\
\text { herbicide }\end{array}$} & \multirow[b]{2}{*}{$\begin{array}{c}\text { POST } \\
\text { herbicide }\end{array}$} & \multirow[b]{2}{*}{ SOA } & \multirow[b]{2}{*}{$\begin{array}{l}\text { POST } \\
\text { timing }\end{array}$} & \multicolumn{2}{|c|}{ Palmer amaranth } & \multicolumn{2}{|c|}{ Waterhemp } \\
\hline & & & & & $\begin{array}{l}\text { 3-4 WA } \\
\text { EPOST }\end{array}$ & $\begin{array}{l}\text { 3-4 WA } \\
\text { LPOST }\end{array}$ & $\begin{array}{l}3-4 \text { WA } \\
\text { EPOST }\end{array}$ & $\begin{array}{l}\text { 3-4 WA } \\
\text { LPOST }\end{array}$ \\
\hline 20 & $\begin{array}{l}\text { Flumioxazin } \\
\quad+\text { pyroxasulfone }\end{array}$ & $\begin{array}{l}S \text {-metolachlor } \\
\quad+\text { glufosinate }\end{array}$ & 3 & LPOST & $22 \mathrm{abc}$ & $19 \mathrm{abcd}$ & $18 \mathrm{a}$ & 10 abcde \\
\hline 21 & $\begin{array}{l}\text { Flumioxazin } \\
\quad+\text { pyroxasulfone }\end{array}$ & $\begin{array}{l}\text { S-metolachlor } \\
\quad+\text { glyphosate } \\
\quad+2,4-\mathrm{D}\end{array}$ & 3 & LPOST & 16 abcde & $22 \mathrm{abcd}$ & $15 \mathrm{abc}$ & 8 abcdefg \\
\hline 22 & $\begin{array}{l}\text { Flumioxazin } \\
\quad+\text { pyroxasulfone }\end{array}$ & $\begin{array}{l}\text { S-metolachlor } \\
\quad+\text { glyphosate } \\
\quad+2,4-\mathrm{D} \\
\quad+\text { glufosinate }\end{array}$ & 4 & LPOST & 11 defg & $13 \mathrm{bcd}$ & $17 \mathrm{a}$ & 10 abcdef \\
\hline 23 & $\begin{array}{l}\text { S-metolachlor } \\
\quad+\text { isoxaflutole } \\
\quad+\text { metribuzin }\end{array}$ & $\begin{array}{l}\text { Glyphosate } \\
\quad+\text { fomesafen }\end{array}$ & 4 & LPOST & $22 \mathrm{abc}$ & $18 \mathrm{abcd}$ & 10 cdef & 9 abcdefg \\
\hline 24 & $\begin{array}{l}\text { S-metolachlor } \\
\quad+\text { mesotrione } \\
\quad+\text { metribuzin }\end{array}$ & fomesafen & 4 & LPOST & $16 \mathrm{abcd}$ & $20 \mathrm{abcd}$ & $16 \mathrm{ab}$ & 7 bcdefg \\
\hline 25 & $\begin{array}{l}S \text {-metolachlor } \\
\quad+\text { fomesafen } \\
\quad+\text { metribuzin }\end{array}$ & $\begin{array}{l}S \text {-metolachlor } \\
\quad+\text { glyphosate } \\
\quad+\text { mesotrione }\end{array}$ & 4 & LPOST & 15 bcdef & $24 \mathrm{abcd}$ & 11 bcde & 6 cdefg \\
\hline 26 & $\begin{array}{l}S \text {-metolachlor } \\
\quad+\text { fomesafen } \\
\quad+\text { metribuzin }\end{array}$ & $\begin{array}{l}\text { S-metolachlor } \\
\quad+\text { glyphosate } \\
\quad+\text { mesotrione } \\
\quad+\text { dicamba }\end{array}$ & 5 & LPOST & $14 \mathrm{cdef}$ & $9 \mathrm{~d}$ & 10 bcdef & $4 \mathrm{fg}$ \\
\hline
\end{tabular}

\footnotetext{
${ }^{a}$ Abbreviations: EPOST, early POST; LPOST, late POST; SOA, number of effective sites of action within each herbicide program with glyphosate excluded because of resistance.

b Means within a column followed by the same lowercase letter are not significantly different.
}

factors (such as irrigated areas). In many situations, herbicides will not provide control for the duration of the critical weed-free period; therefore, an application of a POST herbicide 3 to 5 WA PRE treatment is necessary for maintaining the weed-free period. Waiting to apply a POST herbicide provides an opportunity for newly emerged weeds to compete with the crop and grow to a size that may not be fully controlled by LPOST treatment because all programs with LPOST herbicides had $<95 \%$ control at 3 to 4 WA LPOST application. Furthermore, the critical weed-free period only takes into account yield loss in the current crop, not other potential results of not controlling weeds for the duration of the season, such as replenishment of the soil seedbank.

Practical Implications. The herbicide programs evaluated in these experiments that contained new soybean technologies and PRE fb EPOST herbicides should effectively manage glyphosateresistant waterhemp and Palmer amaranth. Current technologies that include a POST herbicide treatment with an effective site of action (e.g., glufosinate) in combination with a residual product will also control glyphosate-resistant Amaranthus spp. To delay herbicide-resistance, applying residual herbicides PRE and POST to minimize selection pressure on herbicides with only POST activity is recommended (Norsworthy et al. 2012). Furthermore, applications of POST herbicides should occur no later than 3 to 4 WA PRE treatment to ensure that herbicides are applied at labeled weed sizes and that residual herbicides applied POST are effectively used. However, it is possible residual herbicides may not be effective if no rainfall occurs after application. In situations in which little to no rainfall occurs during the weeks following application of residual herbicides, or when canopy closure does not occur (e.g., late-planted 


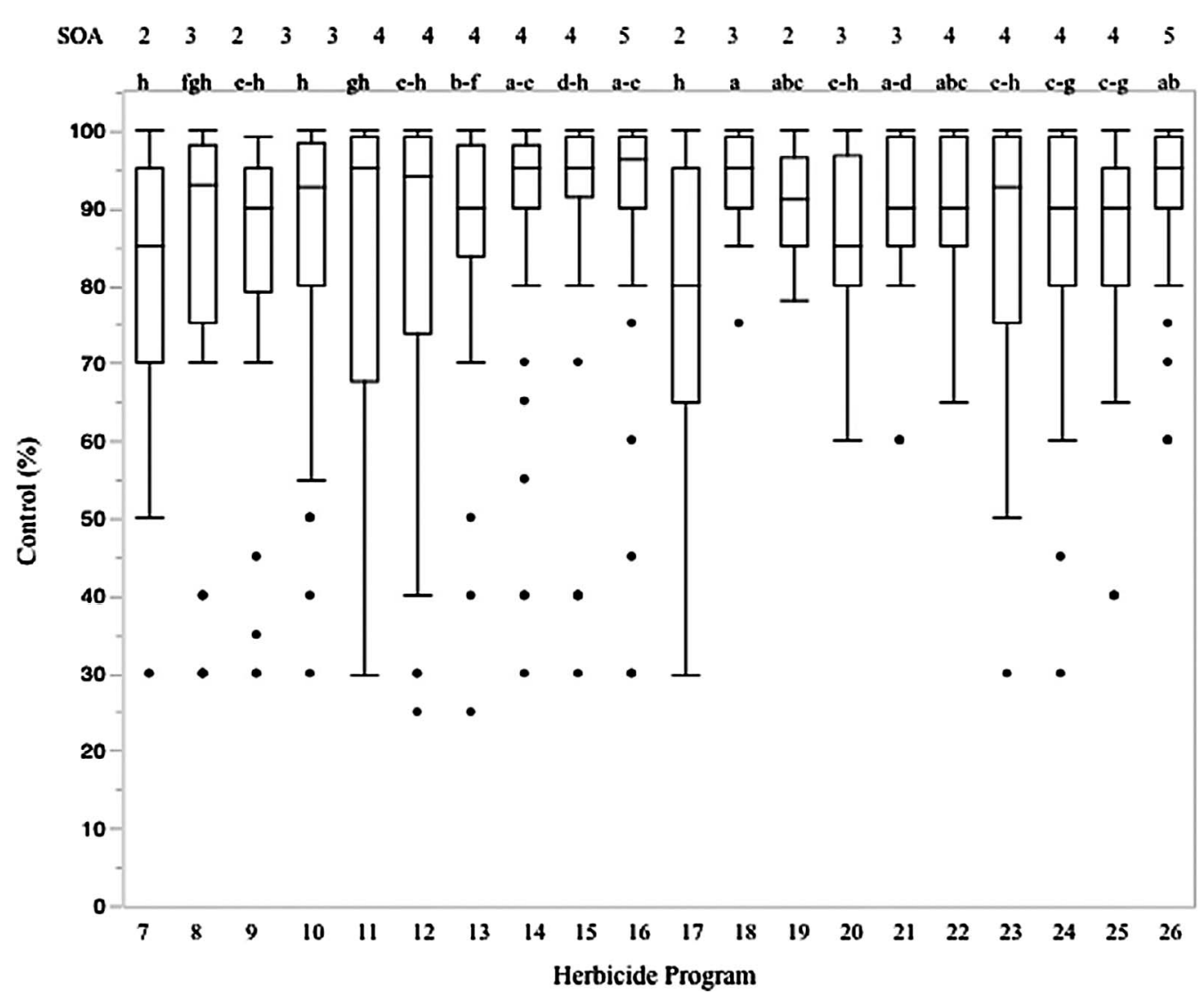

Figure 2. Box and whisker plots depicting Palmer amaranth percent control 3 to 4 weeks after late POST for each herbicide program, and number of effective sites of action (SOA). Means of herbicide programs sharing the same letter are not significantly different according to Fisher's protected LSD $(\alpha=0.05)$. Herbicide program corresponds to the appropriate number listed in Table 4.

soybean or less than recommended crop density), another application of a POST herbicide may be necessary for season-long control.

Most of the herbicide programs evaluated were either comparable or superior to current herbicide programs being used in glyphosate- or glufosinateresistant soybean involving PRE and POST residual herbicides. New technologies could further enhance site-of-action diversity in soybean, lessening the risks of herbicide-resistance evolution (Norsworthy et al. 2012) and improving the control of waterhemp, Palmer amaranth, and other hard-to-control weeds. Using more than one herbicide site of action throughout the

Table 5. Orthogonal contrasts for percent control and density of Palmer amaranth and waterhemp data collected 3-4 wk after the LPOST application. ${ }^{\text {a,b }}$

\begin{tabular}{lcccc}
\hline & \multicolumn{2}{c}{ Palmer amaranth } & \multicolumn{2}{c}{ Waterhemp } \\
\cline { 2 - 4 } Contrast & Control & Density & Control & Density \\
\hline EPOST vs. LPOST & $* * *$ & $* *$ & $* * *$ \\
Current vs. future technologies & $* * *$ & $*$ & $* *$ \\
$2,4-D$ vs. dicamba technologies & NS & NS & NS \\
Auxins vs. HPPD EPOST & $* *$ & NS & NS \\
Auxins vs. HPPD LPOST & $* *$ & NS & $* *$ \\
\hline
\end{tabular}

\footnotetext{
${ }^{a}$ Abbreviations: LPOST, late POST; EPOST, early POST; NS, not significant.

b Significant at the ${ }^{*} \mathrm{P}=0.05$ to $0.01,{ }^{* *} \mathrm{P}=0.01$ to $0.001,{ }^{* * *} \mathrm{P} \leq 0.001$ levels.

${ }^{c}$ Only the programs containing EPOST herbicides were included in the contrast.

${ }^{\mathrm{d}}$ Only the programs containing LPOST herbicide were included in the contrast.
} 


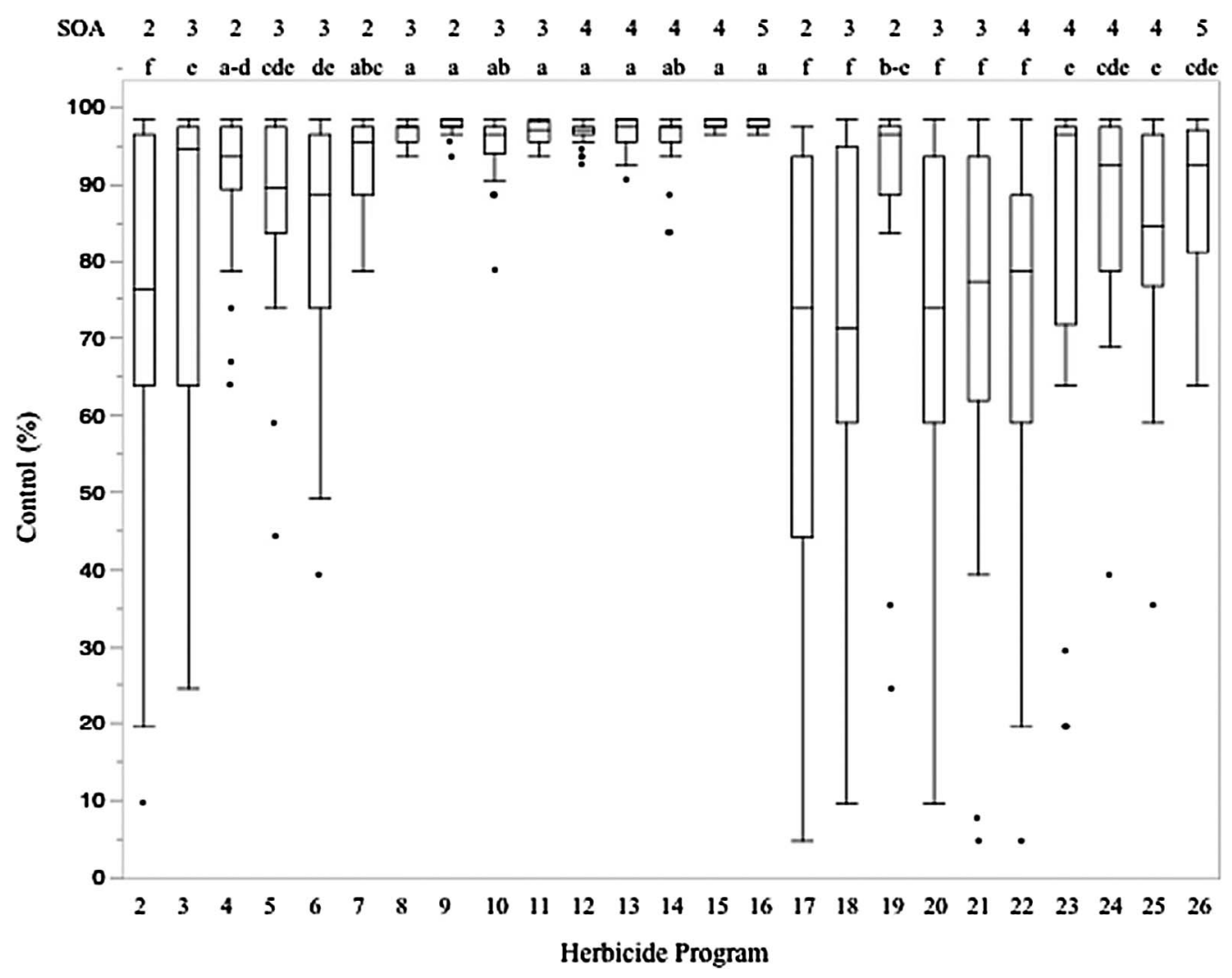

Figure 3. Box and whisker plots depicting the waterhemp percentage of control 3 to 4 wk after early POST for each herbicide program and number of effective sites of action (SOAs). Means of herbicide programs sharing the same letter are not significantly different according to Fisher's protected LSD $(\alpha=0.05)$. Herbicide program corresponds to the appropriate number listed in Table 4.

growing season, and preferably in the same application, will lessen the likelihood of evolving herbicide resistance. Overall, programs using new technologies provided longer and improved control of both Palmer amaranth and waterhemp. In situations that prevent timely PRE and POST applications, applying an auxinic herbicide LPOST will improve control over currently labeled products (i.e., glyphosate and glufosinate) LPOST. Despite the emergence of technologies that will increase the number of chemical weedcontrol options in soybean, weed-management programs that rely solely on a single herbicide are not sustainable (Norsworthy et al. 2012). Populations of Amaranthus spp. have been documented with resistance to the synthetic auxins, HPPDinhibitors, and PPO-inhibitors used in these experiments, as well as resistance to PSII-inhibitors (Heap 2015). Based on the weed-control data from each site-year and historical knowledge of each location, there is no reason to suspect the
Amaranthus spp. populations investigated were resistant to any other herbicides besides the glyphosate used in this experiment. However, Amaranthus spp. populations exist that are resistant to many of the herbicides in the new soybean herbicide programs. Proper integrated weed-management programs that incorporate effective soybean herbicide programs are vital for sustainable herbicide-resistant management. Thus, the successful integration of nonchemical weedmanagement tactics (e.g., biological, cultural, and mechanical practices) along with using the herbicides that can be applied in future herbicideresistant soybean traits will serve as the premise of best management practices.

\section{Acknowledgments}

Funding for this research was made possible by a grant from the United Soybean Board. 


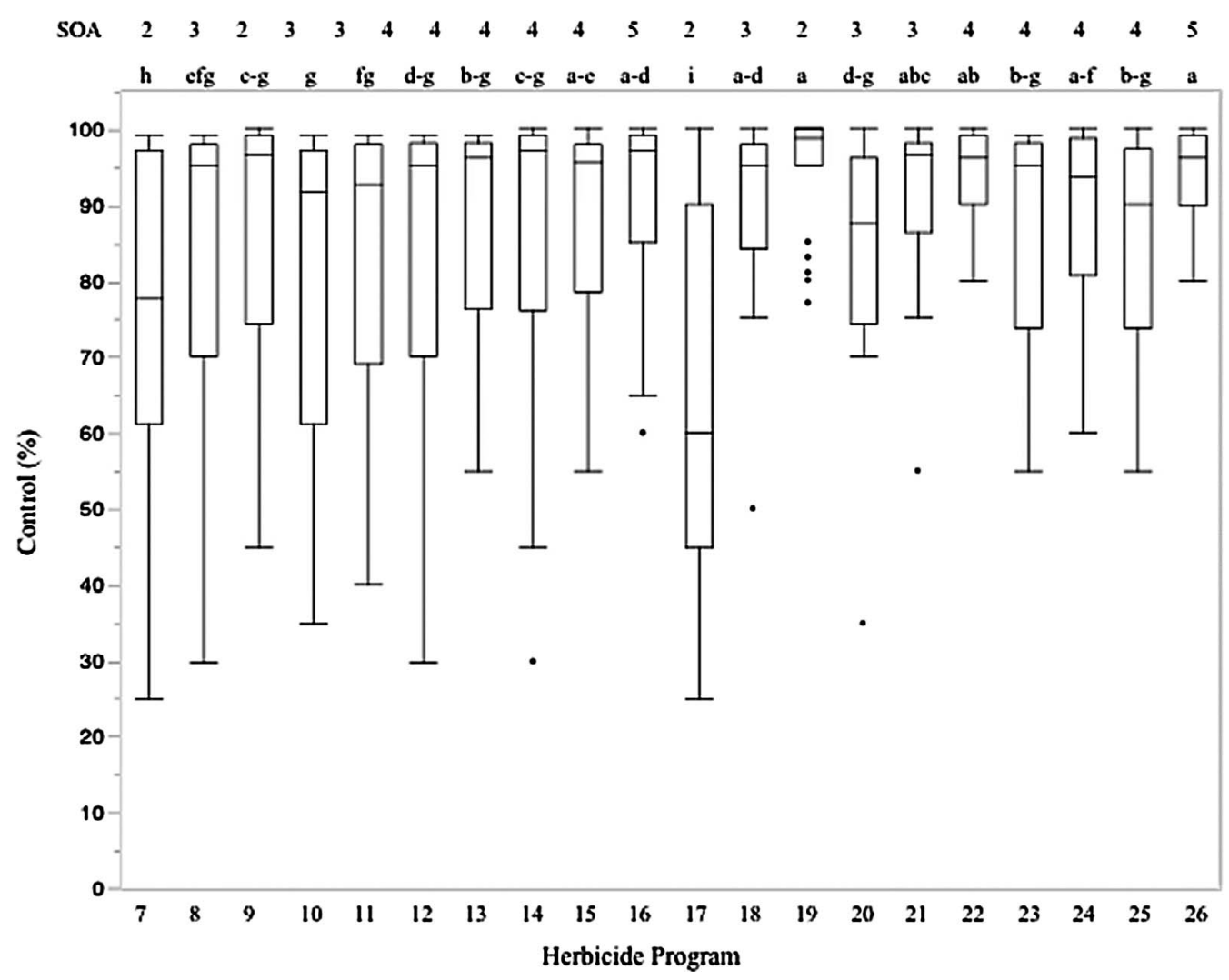

Figure 4. Box and whisker plots depicting waterhemp percent control 3 to 4 wk after late POST for each herbicide program and number of effective sites of action (SOAs). Means of herbicide sharing the same letter are not significantly different according to Fisher's protected LSD $(\alpha=0.05)$. Herbicide program corresponds to the appropriate number listed in Table 4.

\section{Literature Cited}

Anonymous (2011) Warrant herbicide product label. Monsanto Publication No. 36067J2-2. St. Louis, MO: Monsanto Company. $7 \mathrm{p}$

Anonymous (2013) Fierce herbicide product label. Valent Publication No. 2013-FIE-0001. Walnut Creek, CA: Valent U.S.A Corporation. $14 \mathrm{p}$

Bagavathiannan MV, Norsworthy JK (2013) Occurrence of arable weeds in roadside habitats: implications for herbicide resistance management. Proc Weed Sci Soc 53:163 [Abstract]

Bagavathiannan MV, Dotray P, Norsworthy JK (2015) Postharvest seed production potential of Palmer amaranth and waterhemp in the southern US. Proc South Weed Sci Soc 68:38 [Abstract]

Bell MS, Hager AG, Tranel PJ (2013) Multiple resistance to herbicides from four site-of-action groups in waterhemp (Amaranthus tuberculatus). Weed Sci 61:460-468

Bensch CN, Horak MJ, Peterson D (2003) Interference of redroot pigweed (Amaranthus retroflexus), Palmer amaranth (A. palmeri), and common waterhemp (A. rudis) in soybean. Weed Sci 51:37-43

Chahal GS, Johnson WG (2012) Influence of glyphosate or glufosinate combinations with growth regulator herbicides and other agrochemicals in controlling glyphosate-resistant weeds. Weed Technol 26:638-643

Craigmyle BD, Ellis JM, Bradley KW (2013a) Influence of herbicide programs on weed management in soybean with resistance to glufosinate and 2,4-D. Weed Technol 27:78-84

Craigmyle BD, Ellis JM, Bradley KW (2013b) Influence of weed height and glufosinate plus 2,4-D combinations on weed control in soybean with resistance to $2,4 \mathrm{D}$. Weed Technol $27: 271-280$

Heap I (2015) International Survey of Herbicide-Resistant Weeds. http://www.weedscience.com/summary/home.aspx. Accessed February 14, 2015

Horak MJ, Loughin TM (2000) Growth analysis of four Amaranthus species. Weed Sci 48:347-355

Jha P, Norsworthy JK (2009) Soybean canopy and tillage effects on emergence of Palmer amaranth (Amaranthus palmeri) from a natural seed bank. Weed Sci 57:644-651

Jha P, Norsworthy JK, Riley MB, Bielenberg DG, Bridges W Jr (2009) Acclimation of Palmer amaranth (Amaranthus palmeri) to shading. Weed Sci 56:729-734

Johnson WG, Chahal GS, Regeh DL (2012) Efficacy of various corn herbicides applied preplant incorporated and preemergence. Weed Technol 26:220-229

Keeley PE, Carter CH, Thullen RJ (1987) Influence of planting date on growth of Palmer amaranth (Amaranthus palmeri). Weed Sci 199-204 
Klingaman TE, Oliver LR (1994) Palmer amaranth (Amaranthus palmeri) interference in soybeans (Glycine max). Weed Sci 42:523-527

Knezevic SZ, Evans SP, Mainz M (2003) Row spacing influences the critical timing for weed removal in soybean (Glycine max). Weed Technol 17:666-673

Neve P, Norsworthy JK, Smith KL, Zelaya IA (2011) Modeling evolution and management of glyphosate resistance in Amaranthus palmeri. Weed Res 51:99-112

Norsworthy JK, Griffith GM, Scott RC, Smith KL, Oliver LR (2008) Confirmation and control of glyphosate-resistant Palmer amaranth (Amaranthus palmeri) in Arkansas. Weed Technol 22:108-113

Norsworthy JK, Ward SM, Shaw DR, Llewellyn RS, Nichols RL, Webster TM, Bradley KW, Frisvold G, Powles SB, Burgos NR, Witt WW, Barrett M (2012) Reducing the risks of herbicide resistance: best management practices and recommendations. Weed Sci 60:31-62

Riar DS, Norsworthy JK, Steckel LE, Stephenson IV D. Eubank TW, Scott RC (2013) Assessment of weed management practices and problem weeds in midsouth United States soybean: a consultant's perspective. Weed Technol 27:612622

Schultz JL, Chatham LA, Riggins CW, Tranel PJ, Bradley KW (2015) Distribution of herbicide resistances and molecular mechanisms conferring resistance in Missouri waterhemp (Amaranthus rudis Sauer) populations. Weed Sci 63:336-345

Sellers BA, Smeda RJ, Johnson WG, Kendig JA, and Ellersieck MR (2003) Comparative growth of six Amaranthus species in Missouri. Weed Sci 51:329-333
Sutton P, Richards C, Buren L, Glasgow L (2002) Activity of mesotrione on resistant weeds in maize. Pest Manag Sci 58:981-984

Steckel LE (2007) The dioecious Amaranthus spp.: here to stay. Weed Technol 21:567-570

Tranel PJ, Riggins CW, Bell MS, Hager AG (2011) Herbicide resistances in Amaranthus tuberculatus: a call for new options. J Agric Food Chem 59:5808-5812

[USDA-NASS] U.S. Department of Agriculture-National Agricultural Statistics Service (2015) Quick Stats. http:// quickstats.nass.usda.gov/. Accessed February 6, 2015

Van Acker RC, Swanton CJ, Weise SF (1993) The critical period of weed control in soybean [Glycine max (L.) Merr.]. Weed Sci 41:194-200

Webster TM (2013) Southern Weed Science Society Weed Survey. Pages 275-287 in Proceedings of the Southern Weed Science Society Annual Meeting. Houston, TX: Southern Weed Science Society

Webster TM (2012) Southern Weed Science Society Weed Survey. Pages 267-288 in Proceedings of the Southern Weed Science Society Annual Meeting. Charleston, SC: Southern Weed Science Society

Received April 6, 2015, and approved July 7, 2015.

Associate editor for this paper: Aaron G. Hager, University of Illinois 